\title{
Evaluation of nutritional care of overweight adults from the perspective of comprehensive health care
}

\author{
Avaliação da atenção nutricional ao \\ excesso de peso sob a ótica da \\ integralidade em saúde
}

José Anael NEVES ${ }^{1}$

Lia Thieme Oikawa ZANGIROLANI ${ }^{2}$

Maria Angélica Tavares de MEDEIROS²

\section{A B S T R A C T}

\section{Objective}

Describe and evaluate the nutritional care provided for overweight adults by the Primary and Secondary Health Care services of Santos, São Paulo, Brazil.

\section{Methods}

This study was carried out between 2013 and 2015 integrating quantitative and qualitative approaches; it was divided into two phases: (1) characterization and (2) evaluation. In phase 1, a census of Primary Health Care Units $(n=28)$ and Secondary Health Care Units $(n=4)$ was conducted using interviews with health service managers and/or health professionals. Data were analyzed using exploratory data analysis. In phase 2, in-depth interviews were conducted with health service managers and/or health professionals investigating a sample of the Primary Health Care services and the totality of Secondary Health Care services provided. Thematic analysis was carried out using the theoretical framework for comprehensive health care proposed by Pinheiro \& Mattos.

\footnotetext{
1 Universidade Federal de São Paulo, Instituto de Saúde e Sociedade, Programa de Pós-Graduação Alimentos, Nutrição e Saúde. Santos, SP, Brasil.

2 Universidade Federal de São Paulo, Instituto de Saúde e Sociedade, Departamento de Políticas Públicas e Saúde Coletiva. R. Silva Jardim, 136, Vila Mathias, 11015-020, Santos, SP, Brasil. Correspondência para/Correspondence to: MAT MEDEIROS. E-mails: <angelicamedeiros@gmail.com>; <angelica.medeiros@unifesp.br>.

Article based on the master's thesis of JA NEVES intitled: "Atenção Nutricional ao excesso de peso sob a ótica da Integralidade: diagnóstico e avaliação da Atenção Básica e de Média Complexidade em município do Sudeste Brasileiro”. Universidade Federal de São Paulo; 2016.

Support: Conselho Nacional de Desenvolvimento Científico e Tecnológico (Process \#486017_2011-7).
} 


\section{Results}

A total of 40 professionals were interviewed: 36 in the primary health care services and 4 in the secondary health care services. Nutritional care in the Primary Care services is focused on individual care and referrals to other services; nutrition diagnosis and health promotion occur only when overweight is associated with another disease. It was observed that the referral and counter-referral system and intersectorial collaborations were ineffective. In Secondary Care services, nutritional care is focused on clinical care using traditional approaches to nutrition education. Limiting factors for promoting comprehensive care were identified at the two levels of care: unproductive actions, lack of actions for health promotion and protection, and little dialogue between the Primary and Secondary care services.

\section{Conclusion}

Overweight is not an outcome based on Primary and Secondary Care, but rather on prescriptive practices, which are not very effective in promoting users' autonomy. It is necessary to guide the actions taken in these two levels of care to ensure the promotion of effective nutritional care.

Keywords: Health evaluation. Integrality in health. Nutrition policy. Obesity. Public health.

\section{RE S U M O}

\section{Objetivo}

Descrever e avaliar a atenção nutricional aos adultos com excesso de peso, na Atenção Primária e Secundária à Saúde, em Santos, São Paulo.

\section{Métodos}

Estudo de caráter quanti e qualitativo, realizado entre 2013 e 2015, em duas etapas: diagnóstico (1) e avaliação (2). Na etapa 1, fez-se um censo dos serviços de Atenção Primária e Secundária $(n=28)$ e Atenção Secundária a Saúde $(n=4)$, entrevistando gestores elou profissionais; realizou-se análise exploratória dos dados. Na etapa 2, entrevistaram-se, em profundidade, gestores elou profissionais com uma amostra dos serviços da Atenção Primária a Saúde e a totalidade dos de Atenção Secundária a Saúde; realizou-se análise temática, utilizando o referencial teórico de integralidade segundo Pinheiro \& Mattos.

\section{Resultados}

Entrevistaram-se 40 profissionais: 36 na Atenção Primária a Saúde e quatro na Atenção Secundária a Saúde. A atenção nutricional na Atenção Primária a Saúde, restringe-se ao atendimento individual, com encaminhamento a outro ponto; diagnóstico nutricional e ações de promoção da saúde só ocorrem quando o excesso de peso se associa a outra doença; verificaram-se fragilidades na referência e contrarreferência e na efetivação da intersetorialidade. Na Atenção Secundária a Saúde, a atenção nutricional direciona-se ao atendimento clínico, utilizando abordagens tradicionais de educação alimentar. Nos dois pontos de atenção identificaram-se fatores limitantes da integralidade: ações fragmentadas; ausência de ações de promoção e proteção da saúde e pouco diálogo entre a Atenção Primária a Saúde e Atenção Secundária a Saúde.

\section{Conclusão}

O excesso de peso não é um desfecho pautado na Atenção Primária a Saúde e, na Atenção Secundária a Saúde, pauta-se por práticas prescritivas, pouco potentes para promover a autonomia dos sujeitos. Faz-se necessário reorientar as ações nesses dois pontos de atenção, para qualificar a atenção nutricional.

Palavras-chave: Avaliação em saúde. Integralidade em Saúde. Política Nutricional. Obesidade. Nutrição em Saúde Pública.

\section{INTRODUCTION}

Chronic, Noncommunicable Diseases (NCDs) are a serious public health problem worldwide, and obesity is one of their main causes and a modifiable risk factor [1-3].
Based on epidemiological knowledge, several countries have proposed interventions for obesity prevention and control [4-6].

In Brazil, the adult obesity rate has reached more than $50 \%$ [7]. In terms of public policies, the "Plano de ações estratégicas para 
o enfrentamento das doenças crônicas não transmissiveis no Brasil (2011-2022)" (Strategic action plan for combating noncommunicable chronic diseases in Brazil [2011-2022]) [8] proposes integrated health surveillance and promotion and comprehensive care actions to combat NCDs and monitor their modifiable risk factors, including unhealthy eating behaviors and obesity. The "Estratégia intersetorial de prevenção e controle da obesidade ("Intersectoral strategy for the prevention and control of obesity) [9] makes recommendations for states and municipalities for the prevention and control of obesity based on intersectoral actions to promote adequate healthy diet and physical activities, in line with the Política Nacional de Alimentação e Nutrição (PNAN, National Food and Nutrition Policy) [10].

Primary Care is the key locus for interventions to prevent and manage overweight or obesity. The reason is that health professionals, in both traditional Basic Care Units and Family Health Units, work directly with a number of individuals and population groups who live and work in that area. Primary Care Units are responsible for the coordination and organization of the Rede de Atenção à Saúde (RAS, Health Care Network), which also includes Secondary and Tertiary Care, establishing the doctrinal principle of comprehensive care [11,12].

In the context of RAS, nutritional care includes the control of obesity, health promotion practices, diagnostic and therapeutic support, interdisciplinary matrix support, and integration of different levels of care within the RAS enabling the performance of clinical procedures with more sophisticated equipment $[10,13,14]$. Therefore, nutritional care is an important attribute for promoting comprehensive care.

The framework for comprehensive health care proposed by Pinheiro \& Mattos $[15,16]$ was used. It offers guidance on professional ethics and conduct, perceiving the users as socio-historical subjects instead of adopting an anatomo-physiological perspective. This implies reviewing the organization of health services, according to the epidemiological profile of the population, through assistance, preventive, and treatment activities [15-16].

Therefore, the present study was conducted under the assumption that nutritional care is one of the guiding principles for the care of overweight individuals within the RAS. In other words, it means to promote qualified listening of health service users in terms of their family and social contexts and to establish a dialogue with them to promote autonomy for healthier food and lifestyle choices [17-19].

Despite its considerable importance, the knowledge of food nutrition practices is still limited at the Sistema Único de Saúde (SUS, Unified Health System), especially regarding the evaluation of nutritional care of overweight adults [20-22]. Therefore, this study aims to describe and evaluate the food and nutrition actions carried out with overweight adults in Primary and Secondary Care services in the city of Santos (SP).

\section{METHODS}

A census of 28 Primary Care services and 4 Secondary Health Care services was carried out integrating quantitative and qualitative approaches in the city of Santos (SP).

This is an extension of a previous study on food and nutrition actions carried out in Santos, which found that there were fewer actions against obesity than those against other NCDs [23].

This study was approved by the Research Ethics Committee of the Universidade Federal de São Paulo (UNIFESP), with an opinion favorable to its execution (Protocol \#1.243.150).

Located in the metropolitan region of Baixada Santista, on the Southern coast of São Paulo, Santos has an estimated population of 434,359 inhabitants, according to the Instituto Brasileiro de Geografia e Estatística (IBGE, Brazilian Institute of Geography and Statistics) 2016 
census [24]. It is divided into two different areas: the insular area - in which $99.3 \%$ of the population is concentrated, comprised of four regions - Orla (Shoreline): Centro (Downtown), Morros (Hillside area), and Zona Noroeste (Northwest Zone) - and the mainland area, which concentrates $0.7 \%$ of the population. Given its low population density, the mainland area was not included in the study.

Primary Care services of Santos include Basic Care Units (BCUs) and Family Health Units (FHUs); the latter is composed of with small teams of professionals (doctors, nurses, dentists, and community health workers).

The present study was divided into two phases. The first one included the characterization of the nutritional care provided to overweight individuals, which was evaluated in the second phase, as shown in Figure 1.

In phase 1, consisted of pinpointing the actions taken to provide nutritional care for overweight adults at the two levels of care, Primary and Secondary Care, within the RAS to identify the type of actions carried out (individual or collective), the professionals involved, and the frameworks used to guide these practices. Semistructured interviews were conducted with the
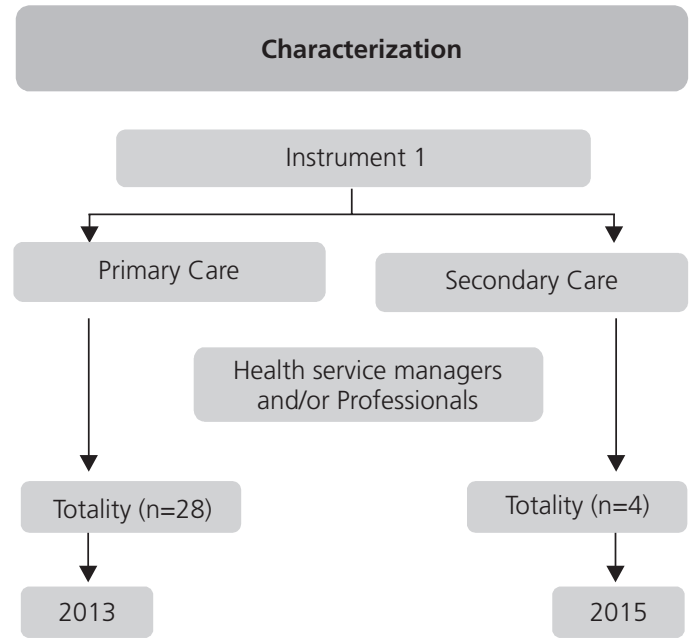

service managers and/or health professionals using instrument 1 (Figure 1) in all services investigated, totaling 28 interviews in the Primary Care services and 4 in Secondary Care services.

Phase 1 interviews were conducted in two different periods of time: in 2013 in Primary Care, as an extension of a previous study [23], and in 2015 in Secondary Care. The same inclusion criteria were adopted in the two phases, but different Primary Care respondents were interviewed in phase 2 .

A pilot study was conducted to test instrument 1 . It included members of the health teams of six Primary Care services in the different regions investigated; these teams were chosen by the service managers. This pilot study allowed reviewing the questions to ensure clarity and objectivity of the instrument contributing, mainly, to reduce interview length. The final version included questions about team composition, work process, food and nutritional surveillance, and nutritional care management.

In phase 1, the characterization of nutritional care of overweight adults provided at the two levels of care within the network enabled writing the interview script used in phase 2 .

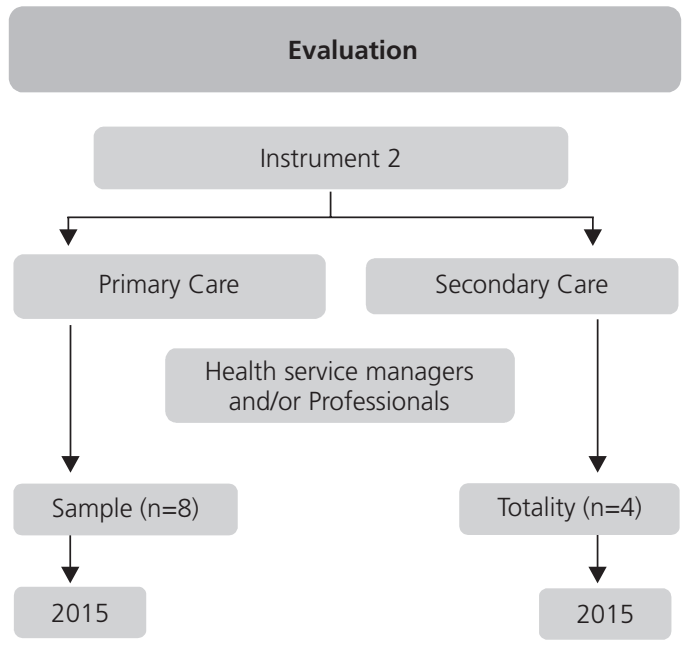

Figure 1. Nutritional care of overweight adults: flowchart outlining the study phases. Santos (SP), Brazil (2015). 
Phase 2 consisted of examining the findings of phase 1 evaluating nutrition actions targeting the overweight adult population. Individual interviews were conducted investigating a sample of the Primary Care services and the totality of the Secondary Care services provided, totaling eight and four interviews, respectively.

One sample representing the two levels of care provided was randomly selected per region of the Santos insular area, totaling eight in-depth interviews in the Primary Care services. Afterwards, four interviews were conducted in the Secondary Care services. Phase 2 data were collected in 2015.

The script of the semi-structured interviews, denominated instrument 2 (Figure 1), used in the second phase of the study, was written based on the framework proposed by Magalhães [25], who recommends evaluating actions or programs by comparing and contrasting theoretical assumptions that support interventions, the interactions between institutions, the available resources, and the social actors involved.

Therefore, the instrument used in phase 2 included questions about the following: health service managers and/or health professionals' perception of comprehensive health care and the care provided for overweight adults; actions carried out; referrals and counter-referral practices; target population adherence to food and nutrition guidelines; and limitation and potential of intersectoral collaboration regarding the management of overweight in adults.

In both phases, the interviewers were previously trained, and the respondents who agreed to participate in the study signed the Informed Consent Form.

The choice of the health service managers and/or health professionals who participated in each phase of the study was made based on their experience and their involvement in the services provided to the population studied, and they were denominated key informants. Key informants included three categories of subjects: health service managers in BCUs and FHUs in the different regions; dietitians; and a few members of the family health team.

Absolute and relative frequencies were calculated on the quantitative data to characterize the food and nutrition actions carried out in the Primary and Secondary Care services.

The qualitative data were analyzed using thematic content analysis, as proposed by Minayo [26]. The evaluation of nutritional care was based on the theoretical framework proposed by Pinheiro \& Mattos $[15,16]$, as previously mentioned.

The interviews were transcribed, and their content was analyzed in three steps: (a) pre-analysis; (b) thorough material analysis; (c) treatment and interpretation of data obtained. Step A consisted of a floating and exhaustive reading of the transcripts to identify general theoretical concepts in the respondents' speeches. Step B included the identification of expressions and/or phrases that were indicative of the interview content organization. Finally, in step $C$, the discourses were grouped into thematic cores and categories defined in the previous steps and were used in the interpretation of dialogues, based on the framework for comprehensive health care $[15,16]$.

\section{RE S U L T S}

A total of 40 interviews were conducted in the 2 phases of this study: 36 in the Primary Care services -28 to identify the actions towards the nutritional care of overweight adults (phase 1) and 8 to evaluate these actions (phase 2) - and 4 in the Secondary Care services.

Of the 28 health service managers and/or health professionals interviewed, 24 were female, 19 were unit managers, 8 were nurses, and 1 was a nurse technician; 20 had 
a postgraduate degree (1 stricto sensu and 19 lato sensu graduate programs). Of the 8 women interviewed to evaluate actions taken at this level of care services (phase 2), 5 were unit managers (1 psychologist and 4 nurses), 1 was a doctor, 1 was a nurse, and 1 was a nurse technician.

Of the 4 professionals interviewed in the Secondary Care services, 3 were female, dietitians, and 1 was a unit manager.

The organization of the nutritional care program for overweight adults in the Primary Care services of Santos (SP) is described in Table 1. The actions concerning food and nutrition care are focused on individual clinical care and were identified in less than half of the services investigated, $42.9 \%(n=12)$. The most common referrals were to a dietitian; however, they were identified in only $28.6 \%(n=8)$ of the services, followed by referrals to the multi-professional team, $25 \%(n=7)$.

Health promotion actions to manage overweight in adults are almost non-existent in the Primary Care services, as shown by the frequencies of groups formed (21.4\%), activities for the waiting room (3.6\%), and specific therapeutic projects (14.3\%).

The nutrition diagnosis in overweight adults, although present in the vast majority of the Primary Care services, was made only when this condition is associated with other NCDs. The following indicators of overweight and obesity were used: weight, in $71.4 \%$ the $(n=20)$, height, in $67.8 \%(n=19)$, waist circumference, in $64.3 \%(n=24)$, glucose levels, in $85.7 \%(n=24)$ lipid profile, in $85.7 \%(n=24)$, blood tests, in $85.7 \%(n=24)$, and uric acid levels, in $75 \%$ of the services $(n=21)$.

As for the use of the Ministry of Health technical manuals, namely the "Caderno de Atenção Básica em Obesidade" (Nutritional care Guidelines for the Management of Obesity) and the "Plano de ações estratégicas para o enfrentamento das doenças crônicas não transmissiveis no Brasil 2011-2022" (Strategic action plan for combating noncommunicable chronic diseases in Brazil [2011-2022]), it was

Table 1. Organization of the nutritional care program for overweight adults in Primary Care services of Santos (SP), Brazil (2015; $n=28)$.

\begin{tabular}{lcc}
\hline Actions to manage overweight & $\mathrm{n}$ & $\%$ \\
\hline Individual Care & 12 & 42.9 \\
$\quad$ Dietitian & 8 & 28.6 \\
Family doctor & 4 & 14.3 \\
Multi-disciplinary team & 25.0 \\
Group health education activities & 7 & 21.4 \\
Waiting room activities & 3.6 \\
Specific therapeutic project & 1 \\
Incentive for participation physical activities & 4 \\
Information materials & 14.3 \\
Use of indicators to support nutrition diagnosis & 46.4 \\
$\quad$ Social Aspects considered in the care of overweight adults* & 9 \\
Monitoring of nutritional status of overweight adults** & 32.1 \\
Use of the Caderno de Atenção Básica em Obesidade, created by the Ministry of Health & 25 \\
Use of the "Ações Estratégicas para o Enfrentamento das DCNT no Brasil 2011-2022", created by the Ministry & 22 \\
of Health & 12 & 48.3 \\
\hline
\end{tabular}

Note: *Procedures adopted only when overweight was associated with other Chronic, Noncommunicable Diseases; ${ }^{* *}$ Monitoring of nutritional status refers to the longitudinal comparison of anthropometric and dietary indicators and social and health aspects.

DCNT: Doenças Crônicas Não Transmissiveis. 
found that only $14.3 \%$ and $10.7 \%$, respectively, of the respondents in Primary Care services reported using them to guide the practices adopted.

Table 2 shows the organization of the nutritional care program for overweight adults in the Secondary Care services of Santos (SP). Individual clinical care was identified in all services, and the most common referrals were to a dietitian, followed by referrals to the endocrinologist and the multi-professional team, both present in $75 \%$ of the services $(n=3)$.

Health education activities were performed in closed groups in three services (75\%); two of them (50\%) reported using the Guia Alimentar da População Brasileira (Dietary Guidelines for Brazilian Population), created by the Ministry of Health in 2014 [27]. Nutrition diagnosis, using anthropometric and biochemical indicators, was a practice adopted in all units providing this level of care.

The speeches of the health service managers and/or health professionals interviewed in the Primary Care and Secondary Care services of Santos (SP), were arranged into thematic cores and categories that supported the analysis of the nutritional care provided for overweight adults (Figure 2).

In the comprehensive health care thematic core, the health service managers and/ or health professionals interviewed expressed the notion of universal access to health services as an opportunity to exercise social citizenship. Moreover, they pointed out that multiprofessional practice is very important when dealing with the complexity among the users to help bring them closer together.

[...] the comprehensive process has a lot to do with being able to [...] perceive people [...] in all dimensions [...] (R11).

[...] to look at the big picture considering everybody; this is dignity; the entire health network has to be committed (R8).

The issues mentioned by the respondents regarding their understanding of comprehensive care refer to aspects that are not incorporated into the daily routine in the health units. However, they are needed to ensure the promotion of effective nutritional care of overweight adults, as summarized below:

[...] provide the care the citizens need

[...] which we are not able to do (R1).

Table 2. Organization of the nutritional care program for overweight adults in Secondary Care services of Santos (SP), Brazil (2015; $\mathrm{N}=4)$.

\begin{tabular}{lcc}
\hline Actions to manage overweight & $\mathrm{n}$ & $\%$ \\
\hline Individual Care & 4 & 100 \\
Dietitian & 4 & 100 \\
Endocrinologist & 3 & 75 \\
Multi-disciplinary team & 3 & 75 \\
$\quad$ Group health education activities & 3 & 75 \\
Incentive for participation physical activities & 4 & 100 \\
Information materials & 3 & 75 \\
Use of indicators to support nutrition diagnosis* & 4 & 100 \\
$\quad$ Social Aspects considered in the care of overweight adults* & 4 \\
Monitoring of nutritional status of overweight adults** & 4 \\
Use of the Guia Alimentar da População Brasileira, created by the Ministry of Health & 4 \\
\hline
\end{tabular}

Note: *Procedures adopted only when overweight was associated with other Chronic, Noncommunicable Diseases; ${ }^{* *}$ Monitoring of nutritional status refers to the longitudinal comparison of anthropometric and dietary indicators and social and health aspects. 


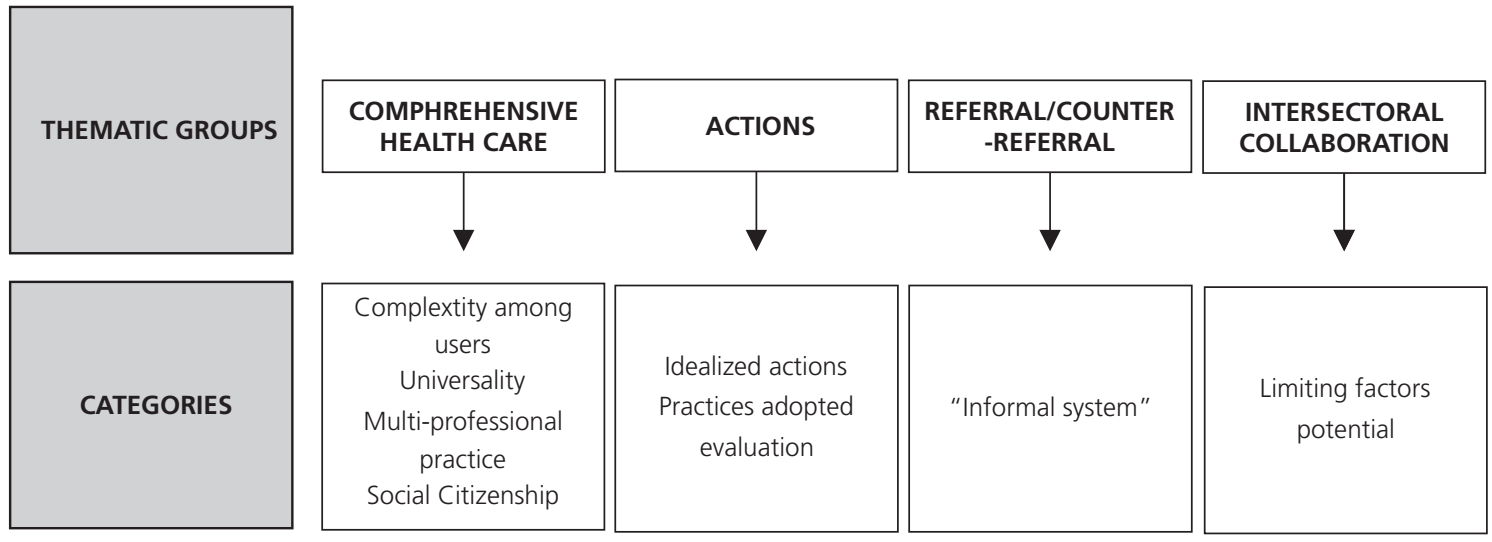

Figure 2. Thematic groups and categories for evaluation of nutritional care of overweight adults, according to health service managers and/or health professionals in Primary Care and Secondary Care services. Santos (SP), Brazil (2015).

With regard to the thematic core actions, there is a gap between ideal actions, referred to as important to ensure comprehensive health care for overweight adults, and the real actions incorporated into the daily routine in the health units. The perspectives of the respondents regarding nutritional care are based on social determinants, recognizing feeding habits as an element of food culture, through the actions taken by the multi-professional team. However, they recognized that, in practice, Primary and Secondary care services are strictly focused on individual clinical care and referrals to other services within the RAS.

[...] the care provided has its own "dimensions"; it has to do with those who are responsible for scheduling the exams, but it is... related to [...], the food culture; it has to do with understanding their life conditions, the world they live in; to enter the world of the person and then decide what you're going to do [...] (R8).

Specifically, we haven't adopted an action for the care of overweight adults [...]. Nutrition reeducation with professional guidance from a dietitian is needed [...], but we don't have a dietitian available here, so we make referrals to other units (R7).
As for the Secondary Care level, all services (four) investigated had registered dietitians available to provide individual clinical care and dietary prescriptions, as stated below.

We provide nutritional and dietary counseling; printed diet prescriptions are handed out, [...], but will the patient be able to follow it? There were professionals here who would open the cabinet and say, "Let's see what we have here; what we can do with it. How can we avoid it? How much oil do you use? Can you show me?" (R7).

In this case, the notion of prescriptive dietary reeducation was the strategy aimed at managing overweight in adults, as mentioned by the professionals:

You know, nutrition re-education is very important ... to teach them how to consume food, like [...] how often they should eat, right? Try to teach them [...]. Nutrition re-education [...] is extremely important because people have [...] a tendency to eat the tastiest foods [...] and usually they are high in calories and fat, right? (R4).

With regard to the evaluation of these actions, the respondents stated that they are carried out occasionally and that they are limited in terms of the number of professionals involved, 
inadequate infrastructure, and non-adherence of users to nutritional recommendations.

[...]/think thata moreadequateworkspace would bring great improvements [...] we would be able to get in touch with groups and have many case discussions. If we are able to think together, to share information, to get more workspace and more professionals [...] without setting aside different isolated small workspaces for nutrition, for physical education [...], I think it would work well (R1).

As for the referrals and counter-referrals, another thematic core organized, the lack of communication between the two levels of care services was frequently mentioned. According to the respondents, they were almost nonexistent, and when they were made, the whole process was slow and bureaucratic. On the other hand, in order to establish a relationship between health workers and service users, the respondents mentioned the existence of an informal referral and counter-referral system.

[...] let's say that the referrals and counter-referrals are informal [...] the patient goes and come back and we can get I them through our connections with the patient [...] if you don't count the informal referral and counter-referral system, there is none (R12).

[...] there's too much paperwork to go around, and it doesn't go anywhere (R9).

In the intersectoral collaboration thematic core, the respondents' speeches indicated that there are potential and challenges to deal with intersectoral collaboration in managing adult overweight. There was a consensus among the respondents that it is impossible to manage overweight without having closer and frequent dialogues between different sectors due to the multi-causal characteristic of overweight.

[...] how can we deal with obesity without a functional intersectoral collaboration? If it is a set of factors [...], to me, it's a big step ... it's ... like I said, we do not work alone; alone, we do not get anything done; health alone cannot do anything (R6).

The respondents also mentioned potential for partnerships with the social assistance sector and dialogues between health services and the university. On the other hand, the absence of relationships with the city's education sector was pointed out as a limiting factor in nutritional care due to the impossibility of planning actions according to the social determinants of overweight.

I think this is important [...] this ability to have intersectoral collaboration, but it does not exist. Or if it exists, it's very uncommon [...] with the education sector, I have never seen, but I have seen it once with the "Centro de Referência da Assistência Social" (CRAS, Social Assistance Reference Center) (R8).

\section{I SCUSSION}

The findings show the presence of ineffective nutritional care practices for the management of overweight in adults in the Primary and Secondary Care services of Santos. Cunha \& Campos [28] also investigated the health care arrangements and identified a steady trend towards inefficiency and lack of responsibility, frequently relegating the importance of health promotion.

During data collection, between 2013 and 2015 (phases 1 and 2), expanded outreach service was implemented at the Primary Care level, promoting access for almost $7.5 \%$ of the city population [29]. Despite the expanded delivery of health care services, it remains below the São Paulo state average, which increased by $9.8 \%$ over the same time period [29]. The reasons for this expansion in Santos are still unclear; it is not possible to affirm that it was due to the implementation of the Núcleos de Apoio à Saúde da Familia (NASF, Family Health Support Team), which started in 2015. 
Despite the implementation of the NASFs in Santos, the integration of dietitians into Primary Care is not enough due to the existing demand. Over the time period investigated, there were only two dietitians working in Primary Care. However, at the national level, the integration of this health professional at this level of care within the RAS remains more limited than that of the Secondary and Tertiary Care levels, despite the significant recent increase in the number of dietitians working in Primary Care $[30,31]$.

According to Rigon et al. [32], the insufficient number of dietitians working in Primary Care within the RAS and holding management positions hinder the implementation of food and nutrition action, failing to meet the existing demand and violating human right to nutritional care.

Nutritional care leads to an integrated RAS, and all Primary Care professionals are responsible for the delivery of nutritional care $[12,17]$. However, in the absence of dietitians, the other health professionals face challenges in providing dietary counseling due to their lack of training $[33,34]$.

It was found that the nutrition diagnosis and the monitoring of nutritional status of overweight adults, which was associated to the presence of other NCDs, suggest an approach focused on the compliance with the guidelines issued by the Sistema de Cadastramento e Acompanhamento de Hipertensos e Diabéticos do SUS (HiperDia, System for Registration and Monitoring of Hypertensive and Diabetic Patients at the SUS) [35]. It also indicates the prioritization of the treatment of diseases, neglecting disease prevention and health promotion, failing to adhere to the food and nutritional surveillance guidelines set out by the PNAN, which are essential for the organization of nutritional care within the RAS.

The use of the "Caderno de Atenção Básica em Obesidade" and the "Plano de Ações estratégicas para o enfrentamento das doenças crônicas não transmissíveis no Brasil" seems irrelevant in the Primary Care services of Santos. However, this result differs from that found by Laporte-Pinfildi et al. [36], who reported proper implementation and use of Ministry of Health manuals in the context of nutritional care during prenatal and postpartum periods in Santos. The present study suggests further investigation of the use of Ministry of Health technical materials to guide the practices adopted in these services.

Most of the Secondary Care services investigated provide individual clinical care and undertake group activities for Primary Care referrals. However, when emphasizing dietary reeducation as a tool to promote good eating habits, their practices are based on prescriptive approaches.

It is known that access to food and nutrition information is extremely important for the implementation of healthy eating practices, but it is not enough. Information sharing alone is not effective in the management of overweight as it is not able to promote autonomous choice for eating behavior change. Furthermore, it does not focus on the social determinants of overweight and on the life history of patients and their access to healthy foods (9). This practice is contrary to the recommendations of the Guia Alimentar da População Brasileira [27], available in half of the of Secondary Care services of Santos.

Evaluating the integration of dietitians into the SUS services in a Brazilian capital city, Rodrigues \& Bosi [37] also found predominance of individual and technical practices and insufficient reflection about this issue. Therefore, this is another report of practices that do not adhere to the SUS principles.

Although the integration of dietitians into the SUS is not the focus of the present study, the results obtained show the need for investments to ensure the promotion of effective practices. Accordingly, studies have pointed out the ineffective training of professionals working in the SUS, such as few academic disciplines related to nutritional care practices to be implemented 
in the RAS $[32,38,39]$. Thus, it can be said that the practices used are not suited to these health services and the epidemiological scenario.

In addition to the elements discussed above, it is important to highlight structuring aspects in the definition of priorities and implementation of nutritional care programs in the SUS. These aspects include multiple needs and disputes over available resources between different sectors. Thus, although the vital role of food and nutrition in health is recognized, it does not guarantee it will be given priority in the services offered by the SUS [32].

One possible reason is that the inadequate nutritional care provided by the SUS services indicates the peripheral position of health promotion actions [28]. This may be due to the fact the health care model adopted is based on treatment and rehabilitation, focused on prescriptive and individual practices [37].

It is important to analyze the contributions and challenges of RAS everyday programs and practices to promote comprehensive health care $[40,41]$. On the other hand, the nutritional care provided by the SUS services should be more effectively incorporated in the network, and comprehensive health care should be the aim of the practices adopted [32].

Based on the theoretical framework used in the present study $[15,16]$, the qualitative results obtained show that the respondents' perception of comprehensive care is not a reality in the services provided thus hindering overweight management. Multi-professional work, a more comprehensive clinic, users' access to the different levels of care services provided by RAS, and the integration of these aspects as an exercise of social citizenship and rights represent an ideal condition to be attained in order to promote adequate and effective nutritional care.

Therefore, there is a gap between what the respondents consider important for the comprehensive care of the overweight adults and the care provided. The main reasons mentioned by them are the reduced number of professionals, both in Primary and Secondary Care, inadequate infrastructure, limited professional collaboration, and little intersectoral dialogue.

The actions carried out in the services are focused on individual clinical care and referrals to other services within the RAS. Clinical care approaches in Primary Care and Secondary Care are focused on sharing information about the nutritional value of foods since they are focused on dietary prescription and traditional nutrition re-education practices.

These findings corroborate those of Cervato-Mancuso et al. [30] and Rodrigues \& Bosi [37]. According to these authors, nutritional care practices with these characteristics are not inserted into the context the users live in and are dissociated from their life history, the complexity among the regions where the health services are located, and the determinants of health.

The referral and counter-referral system of the nutritional care provided for overweight adults in Santos is inefficient thus hindering the provision of comprehensive care, according to the respondents. Nutritional care in Primary Care is expected to be adequate and effective in preventing obesity and diseases associated with unhealthy eating habits to avoid referrals to other services within the RAS due to complications [33].

In the present study, it was observed that biomedical rationality still prevails in the implementation of actions related to management of overweight. On the other hand, the nutritional care actions follow the recommendations of the Plano Estadual de Saúde de São Paulo (20122015) (São Paulo State Health Plan) [42], which does not include any guidelines for overweight prevention and control. Therefore, this plan is not aligned with the country's macro-political health care arrangements, which consider overweight management as a first priority in the care provided within the RAS $[8,9]$.

It was found that intersectorial collaboration in managing adult overweight in the context 
investigated is limited. Despite the recognition of the multi-causal characteristic of obesity and the social determinants of health, the transversality of actions and the dialogue with the Education and Social Assistance sectors were identified as persistent difficulties. Nonetheless, there has been constructive and effective dialogue between the university and the services provided aiming to achieve comprehensive care in Santos $[18,43]$. It is worth noting that managing overweight without intersectoral collaboration worldwide has proved to be ineffective $[44,45]$.

Several limiting factors for achieving comprehensive care of overweight adults were identified at the two levels of care investigated. Among them are the lack of actions to promote health and prevent diseases; unproductive and normative actions, and lack of dialogue between the Primary and Secondary care services. It was concluded that overweight is not a nutritional outcome based on the Primary Care services of Santos and that Secondary Care is focused on the treatment with prescriptive practices that are not effective in promoting user autonomy. The primacy to actions targeting treatment over health promotion actions is a management model adopted in the services investigated, which seem not to perceive overweight as a modifiable risk factor for other chronic conditions that affect the population. Therefore, it is necessary to guide the actions taken in these two levels of care to ensure the promotion of effective nutritional care within the SUS in Santos.

\section{CONTRIBUTORS}

JA NEVES contributed to the conception and design of this study, to data analysis and discussion, and manuscript writing. LTO ZANGIROLANI contributed to the discussion of the results and critical revision of the manuscript. MAT MEDEIROS contributed to the conception and design of the study and to data analysis, and discussion of the results, and manuscript writing.

\section{REFERE N CES}

1. World Health Organization. World Health Statistics 2012. Geneva: WHO; 2012.

2. Marie NG, Fleming $T$, Robinson $M$, Thomson $B$, Graetz N, Margono C, et al. Global, regional, and national prevalence of overweight and obesity in children and adults during 1980-2013: A systematic analysis for the Global Burden of Disease Study 2013. Lancet. 2014;384(9945):766-8. https://doi. org/10.1016/S0140-6736(14)60460-8

3. Roberto CA, Swinburn B, Hawkes C, Huang TTK, Costa SA, Ashe M, et al. Patchy progress on obesity prevention: Emerging examples, entrenched barriers, and new thinking. Lancet. 2015;385(9985):13-9. https://doi.org/10.1016/S01 40-6736(14)61744-X

4. Gortmaker SL, Swinburn B, Levy D, Carter R, Mabry PL, Finegood $D$, et al. Changing the future of obesity: Science, policy and action. Lancet. 2011;378(9793):838-47. https://10.1016/S01406736(11)60815-5

5. Jilcott Pitts SB, Whetstone LM, Wilkerson JR, Smith TW, Ammerman AS. A community-driven approach to identifying "winnable" policies using the Centers for Disease Control and Prevention's Common Community Measures for Obesity Prevention. Prev Chronic Dis. 2012;9:110195. https://doi.org/10.5888/pcd9.110195

6. Leeman J, Sommers J, Vu M, Jernigan J, Payne $G$, Thompson D, et al. An evaluation framework for obesity prevention policy interventions. Prev Chronic Dis. 2012;9:110322. https://doi.org/10. 5888/pcd9.110322

7. Ministério da Saúde (Brasil). Secretaria de Vigilância em Saúde. VIGITEL Brasil 2015. Vigilância de fatores de risco e proteção para doenças crônicas por inquérito telefônico. Brasília: Ministério da Saúde; 2015.

8. Ministério da Saúde (Brasil). Plano de ações Estratégicas para o enfrentamento das Doenças Crônicas Não Transmissíveis (DCNT) no Brasil 2011-2022. Brasília: Ministério da Saúde; 2011.

9. Câmara Interministerial de Segurança Alimentar e Nutricional. Estratégia intersetorial de prevenção e controle da obesidade: recomendações para estados e municípios. Brasília: CAISAN; 2014.

10. Ministério da Saúde (Brasil). Secretaria de Atenção à Saúde. Política Nacional de Alimentação e Nutrição. Brasília: Ministério da Saúde; 2012.

11. Macinko J, Harris MJ, Phil D. Brazil's Family Health Strategy: Delivering community-based primary care in a universal health system. $\mathrm{N}$ Engl J Med. 
2015;372(23):2177-81. https://doi.org/10.1056/ NEJMp1501140

12. Mendes EV. As redes de atenção à saúde. Brasília: Organização Pan-Americana da Saúde; 2011.

13. Ministério da Saúde (Brasil). Secretaria de Atenção à Saúde. Matriz das ações de alimentação e nutrição na atenção básica de saúde. Brasília: Ministério da Saúde; 2009

14. Ministério da Saúde (Brasil). Secretaria de Atenção à Saúde. Estratégias para o cuidado da pessoa com doença crônica. Cadernos de Atenção Básica, nº 38. Brasília: Ministério da Saúde; 2014.

15. Pinheiro R, Mattos RA. Construção da integralidade: cotidiano, saberes e práticas em saúde. $3^{a}$ ed. Rio de Janeiro: Abrasco; 2005.

16. Pinheiro R, Mattos RA. Os sentidos da integralidade na atenção e no cuidado à saúde. $4^{a}$ ed. Rio de Janeiro: Abrasco; 2006.

17. Medeiros MAT. Desafios do campo da alimentação e nutrição na Atenção Básica. In: Diez-Garcia RW, Cervato-Mancuso AM, coordenadores. Mudanças alimentares e educação nutricional. Rio de Janeiro: Guanabara Koogan; 2011. p.173-80.

18. Medeiros MAT, Braga-Campos FC, Moreira MIB. A integralidade como eixo da formação em proposta interdisciplinar: estágios de Nutrição e Psicologia no campo da Saúde Coletiva. Rev Nutr. 2014;27(6):785-98. https://doi.org/10.1590/14 15-52732014000600012

19. Rodrigues EM, Soares FPTP, Boog MCF. Resgate do conceito de aconselhamento no contexto do atendimento nutricional. Rev Nutr. 2005;18(1):119-28. https://doi.org/10.1590/S14 15-52732005000100011

20. Canesqui AM. Pesquisas qualitativas em nutrição e alimentação. Rev Nutr. 2009;22(1):125-39. https:// doi.org/10.1590/S1415-52732009000100012

21. Canella DS, Silva ACF, Jaime PC. Produção científica sobre nutrição no âmbito da Atenção Primária à Saúde no Brasil: uma revisão de literatura. Ciênc Saúde Coletiva. 2013;18(2):297-308. http://doi. org/10.1590/S1413-81232013000200002

22. Vasconcelos FAG. The construction of scientific knowledge in Food and Nutrition: Analysis of dissertations and theses in the Brazilian postgraduation programs in Nutrition. Rev Nutr. 2015;28(1):5-16. https://doi.org/10.1590/1415-52 732015000100001

23. Medeiros MAT, Zangilorani, LTO, Martins PA, Braga-Campos FC, Laporte-Pinfildi AS, Spina N. A integralidade da atenção e as ações de nutrição na atenção básica de santos. Relatório Final de Pesquisa. Santos: Unifesp; 2014.
24. Instituto Brasileiro de Geografia e Estatística. IBGE cidades: Santos - Censo 2010. Rio de Janeiro: IBGE; 2010 [acesso 2016 ago 16]. Disponível em: http://www.ibge.gov.br/cidadesat/link.php? codmun $=354850$

25. Magalhães R. Implementação de programas multiestratégicos: uma proposta de matriz avaliativa. Ciênc Saúde Coletiva. 2014;19(7):2115-23. https://doi.org/10.1590/1413-81232014197.08 482013

26. Minayo MCS, organizador. Pesquisa social: teoria, método e criatividade. 29a ed. Petrópolis: Vozes; 2010.

27. Ministério da Saúde (Brasil). Secretaria de Atenção à Saúde. Guia alimentar para a população brasileira. 2ª ed. Brasília: Ministério da Saúde; 2014.

28. Cunha GT, Campos GWS. Apoio matricial e atenção primária em saúde. Saúde Soc. 2011;20(4):961-70. https://doi.org/10.1590/S0104-1290201100 0400013

29. Instituto Brasileiro de Geografia e Estatística. Teto, credenciamento e implantação das estratégias de Agentes Comunitários de Saúde, Saúde da Família e Saúde Bucal. Município - Santos/SP. Rio de Janeiro: IBGE; 2016 [2017 jan 5]. Disponível em: http://dab.saude.gov.br/portaldab/historico_ cobertura_sf.php

30. Cervato-Mancuso AM, Tonacio LV, Silva ER, Vieira VL. A atuação do nutricionista na Atenção Básica à Saúde em um grande centro urbano. Ciênc Saúde Coletiva. 2012;17(12):3289-300. https:// doi.org/10.1590/S1413-81232012001200014

31. Vasconcelos IAL, Sousa MF, Santos LMP. Evo-lução do quantitativo de nutricionistas na Atenção Básica do Brasil: a contribuição dos Núcleos de Apoio à Saúde da Família e da Estratégia Saúde da Família de 2007 a 2013. Rev Nutr. 2015;28(4):431-50. https://doi.org/10.1590/14 15-52732015000400009

32. Rigon SA, Schmidt ST, Bógus CM. Desafios da nutrição no Sistema Único de Saúde para construção da interface entre a saúde e a segurança alimentar e nutricional. Cad Saúde Pública. 2016;32(3):e00164514. https://doi.org/10.1590/0 102-311X00164514

33. Junqueira TS, Cotta RMM. Matriz de ações de alimentação e nutrição na Atenção Básica de Saúde: referencial para a formação do nutricionista no contexto da educação por competências. Ciênc Saúde Coletiva. 2014;19(5):1459-74. https://doi. org/10.1590/1413-81232014195.11932013

34. Santos AC. A inserção do nutricionista na estratégia da saúde da família: o olhar de diferentes trabalhadores da saúde. Fam Saúde Desenv. 2005;7(3):257-65. https://doi.org/10.5380/fsd.v7i 3.8033 
35. Ministério da Saúde (Brasil). Secretaria de Atenção à Saúde. Plano de reorganização da atenção: hipertensão arterial e diabetes Mellitus. Brasília: Ministério da Saúde; 2002.

36. Laporte-Pinfildi ASC, Zangirolani LTO, Spina N, Martins PA, Medeiros MAT. Atenção nutricional no pré-natal e no puerpério: percepção dos gestores da Atenção Básica à Saúde. Rev Nutr. 2016;29(1):109-23. https://doi.org/10.1590/16 78-98652016000100011

37. Rodrigues DCM, Bosi MLM. O lugar do nutricionista nos Núcleos de Apoio à Saúde da Família. Rev Nutr. 2014;27(6):735-46. https://doi. org/10.1590/1415-52732014000600008

38. Recine $E$, Gomes RCF, Fagundes AAF, Pinheiro ARO, Teixeira BA, Sousa JS, et al. A formação em saúde pública nos cursos de graduação de nutrição no Brasil. Rev Nutr. 2012;2(1):21-33. https://doi. org/10.1590/S1415-52732012000100003

39. Alves CGL, Martinez MR. Lacunas entre a formação do nutricionista e o perfil de competências para atuação no Sistema Único de Saúde (SUS). Interface. 2016;20(56):159-69. https://doi.org/10. 1590/1807-57622014.1336

40. Uchoa AC, Souza E, Spinelli AFS, Medeiros RG, Peixoto DCS, Silva RAR, et al. Avaliação da satisfação do usuário do Programa de Saúde da Família na zona rural de dois pequenos municípios do Rio Grande do Norte. Physis. 2011;21(3):1061-76. https://doi.org/10.1590/S010 3-73312011000300016
41. Comes Y, Trindade JS, Pessoa VM, Barreto ICHC, Shimizu, Helena Eri, et al. A implementação do Programa Mais Médicos e a integralidade nas práticas da Estratégia Saúde da Família. Ciênc Saúde Coletiva. 2016;21(9):2729-38. https://doi. org/10.1590/1413-81232015219.15472016

42. Teixeira JMC, Portas SLC, Vallim S, Mendes JDV, Rodrigues EL, organizadores. Plano estadual 2012-2015. São Paulo: Secretaria da Saúde; 2012.

43. Laporte-Pinfildi ASC, Medeiros MAT. Nutritional care during prenatal and postpartum periods: A report of experiences in a city on São Paulo's coast. Rev Nutr. 2016;29(6):947-61. https://doi. org/10.1590/1678-8652016000600016

44. Jilcott Pitts SB, Whetstone LM, Wilkerson JR, Smith TW, Ammerman AS. A community-driven approach to identifying "winnable" policies using the Centers for Disease Control and Prevention's Common Community Measures for Obesity Prevention. Prev Chronic Dis. 2012;9:110195. https://doi.org/10.5888/pcd9.110195

45. Hawkes C, Ahern AL, Jebb SA. A stakeholder analysis of the perceived outcomes of developing and implementing England's obesity strategy 2008-2011. BMC Public Health. 2014;14:441. https://doi.org/10.1186/1471-2458-14-441

Received: October 18, 2016

Final version: February 10, 2017 Approved: April 12, 2017 